\title{
Intangible Cultural Heritage and inventory process of the Lombardy region
}

\author{
Maria A. Lavagnino
}

For citation: Lavagnino, Maria A. 2020. Intangible Cultural Heritage and inventory process of the Lombardy region. Pravovedenie 64 (1): 68-79. https://doi.org/10.21638/spbu25.2020.106

\begin{abstract}
The article presents the experience of a regional state institution involved in the process of compiling the Regional Intangible Cultural Heritage (ICH) Register in the spirit of the 2003 Convention. The Lombardy Region Ethnography and Social History Archive (Archivio di Etnografia e Storia Sociale, AESS) has been operating since the 1970s within the regional institution for the enhancement of the Lombardy Region's traditional heritage. The Archive has since been used to promote fieldwork and ethnographic research projects and it has been supplemented with documents, photographs and audio-visual documentation. The Italian ratification of the 2003 UNESCO Convention was an opportunity to give continuity and consistency to the cultural activities that the Lombardy Region Ethnography and Social History Archive has been conducting since the 1970s. Regional Law no. 27 of 23 October 2008, "Enhancement of the intangible cultural heritage", and the new Regional Law of Lombardy no. 25 of 7 October 2016 on "Regional policies on cultural matters - Regulatory reorganization" allowed a participatory inventory process and shaped the formation of pioneering legislative action in Italy. As a result of this new regional cultural policy, the Intangible Search Inventory was established, overseen by the AESS, which coordinates safeguarding measures, actions and projects. The Intangible Search Inventory is a community based inventory that adopts the 2003 Convention principles for the safeguarding of $\mathrm{ICH}$ and works to apply the key ideas of the Convention itself, including participation and communities in the identification and description of the $\mathrm{ICH}$ elements. The Archive is also in charge of the production, collection and enhancement of multimedia documentation on $\mathrm{ICH}$. This extends to multimedia collections regarding rituals, social habits, traditional technical knowledge, oral expressions and traditional music. Some of this thematic fieldwork and multimedia materials can be further explored on www.intangiblesearch.eu.
\end{abstract}

Keywords: regional law, living heritage, identifying, inventorying, communities, safeguarding, participative processes.

\section{Introduction: the regional context}

The General Directorate Autonomy and Culture of the Lombardy Region operates in the field of the Intangible Cultural Heritage ( $\mathrm{ICH}$ ) through the Regional Law no. 25 of October 7, 2016 on "Regional policies on cultural matters - Regulatory reorganization" which recognizes $\mathrm{ICH}$ as a strategic tool at institutional level, to enhance it in its various domains and expressions through the Ethnography and Social History Archive (Archivio di Etnografia e Storia Sociale, AESS), following different lines of action (Article 13 and Article 22) ${ }^{1}$.

Maria Agostina Lavagnino - Lombardy Region Ethnography and Social History Archive, 1, Piazza Città di Lombardia, Milan, 20124, Italy; maria_agostina_lavagnino@regione.Iombardia.it

1 The Lombardy Region Ethnography and Social History Archive (Archivio di Etnografia e Storia Sociale, AESS) has been operating since the 1970s within the regional Institution for the enhancement of the Lombardy Region's traditional heritage. Available at: www.aess.regione.lombardia.it (accessed: 14.03.2020).

() St. Petersburg State University, 2021 
The purpose of writing about the Lombardy Region Ethnography and Social History Archive experience is to light the context in which the activity of the Regional Archive operates, discussing and reflecting about the issues concerning $\mathrm{ICH}$, the development of tools and methods in this fieldwork researches area as a strategic issue of changing process in cultural approaches and policies.

The Lombardy Region Ethnography and Social History Archive has been operating since the 1970s within the regional Institution for the enhancement of the Lombardy Region's traditional heritage. The Archive has since been used to promote fieldwork and ethnographic research projects and has been increased with documents, photos and audiovisual documentation. It promotes knowledge, conservation, enhancement and public use of the audio-visual documentary heritage, as related to social life, popular traditions, socio-economic and landscape transformations, as well as to work, literature and oral history, singing and traditional music of the Lombardy Region, with particular attention to ethno-anthropological assets and intangible cultural heritage.

The fifty years activities of this Public Cultural Institute testify the constant attention to those creative actions continuously carried out by local communities, within the framework of their traditional practices, which are recognized by the 2003 UNESCO Convention and later by our national and regional legislation. The Archive developed an important work of collection, documentation, cataloguing, dissemination (editorial series, records, films, multimedia products, public consultation services) of the cultural heritage of the Lombardy Region territorial communities ${ }^{2}$. Since the beginning, these activities has been carried out in cooperation with Local Authorities, Research Institutions, Universities, Nonprofit sector Bodies, Public and Private Foundations committed to the preservation and enhancement of the cultural heritage, experimenting cultural mediation strategies.

As mentioned before, the Archive has always paid attention to the traditional cultural assets, the living practices of the Lombard communities, following the methodology of the anthropological fieldwork. In all the fieldwork researches there has always been the intuition of the existence of distinguishable cultural characters and specificities local cultural values.

In this perspective, traditional cultural heritage has always been considered a potential resource for local development, first in terms of safeguarding and governance, and then as an attractive factor for local and sustainable development.

Archive's strategy has been defined in the introduction to the "Quaderni di Documentazione Regionale" in $1972^{3}$. The document contains important principles about strategic planning actions and innovative governance policy. The notion of giving a "global cultural meaning to political actions" means paying attention to all the cultural phenomena that constitute the components of the Lombardy reality, not only historical, but also the contemporary components which are in close connection with the communities. It means giving a voice to the bearers of living heritage: they are the "men of today, alive and active", "they are the Lombardy citizens of the Seventies"; they are the communities, groups and individuals of today, they are the social actors of the Intangible Cultural Heritage who, in line with the UNESCO principles, are the bearers and, at the same, time the "curators" of the safeguarding and viability processes of Intangible Cultural Heritage.

The conducting of research based on fieldwork, the cultural planning activities, the know-how of the regional territory creates an opportunity for the Archive, with the 2003 Convention and its national ratification, to shape the fulfilment of a pioneering legislative action in Italy.

${ }^{2}$ See editorial projects, records and multimedia collections on www.aess.regione.lombardia.it and fieldwork researches on www.aess.regione.lombardia.it/ricerca (accessed: 14.03.2020). The Institution collections has a huge collections of digital records, mostly available online.

${ }^{3}$ Leydi R. Le trasformazioni socio-economiche e la cultura tradizionale in Lombardia // Cultura tradizionale in Lombardia / ed. by R. Leydi. Milan: Department of Culture, 1972. P. 7-11. 


\section{The international and national legal framework: the community and civil society participation}

The Convention for the Safeguarding of the Intangible Cultural Heritage, adopted by the United Nations Educational, Scientific and Cultural Organization (UNESCO) on 17 October 2003 and ratified by Italy in 2007 with law no. 167 of 27 September 2007, introduced new governance and cultural policy strategies at an international level ${ }^{4}$. The concept of cultural heritage encompasses the practices, representations, expression, knowledge and skills that communities, groups or individuals identify and recognize as their own. Above all, the Convention recognized and established a new heritage category. Furthermore, UNESCO insists that the patrimonialization process depends on the participation of those who practice and transmit these cultural assets.

The text of the Convention shifts the attention from the "experts" to the actors of the $\mathrm{ICH}$, who are not only identified as the bearers, but also ensure its vitality and transmission and must therefore concretely participate in the development of governance strategies that ensure its safeguarding in a "bottom up" process.

The safeguarding concept, very different from the "tutela" one, traceable in the Italian national law texts ${ }^{5}$, includes the dynamic nature of the intangible heritage: a concept that totally transforms the institutional and scientific approach to intangible assets. Their living nature is aimed at accepting changes and new demands in the transmission process. Safeguarding means measures aimed at "ensuring the viability of the intangible cultural heritage" and, naturally, social actors have a fundamental role in the participatory management of their heritage. As stated in Article 2 of the Convention, intangible cultural heritage "is constantly recreated by communities and groups in response to their environment, their interaction with nature and their history, and provides them with a sense of identity and continuity, thus promoting respect for cultural diversity and human creativity". Among the measures that ensure the viability of $\mathrm{ICH}$, and its transmission from generation to generation, stand identification and inventory.

UNESCO's attention of communities and individuals participation is reflected in other international documents, starting from the 2005 Council of Europe Framework Convention, the Faro Convention ${ }^{6}$, ratified by Italy on 23 September 2020, which in fact promotes participation as an essential factor for the cultural heritage management and refers, in its definition, to the communities to which it belongs, introducing the idea of "heritage community", taking up some of the principles set out in the 2003 Convention for the Safeguarding of Intangible Cultural Heritage.

The Faro Convention defines "cultural heritage" and "heritage community" in Article 2:

Article 2 - Definitions

For the purposes of this Convention,

a) cultural heritage is a group of resources inherited from the past which people identify, independently of ownership, as a reflection and expression of their constantly evolving values,

4 The ratification law is published in: Gazzetta Ufficiale. 2007. 12 October. No. 238.

5 The Legislative Decree No. 42 of January 22, 2004 "Code of Cultural Properties" contains only an Article, added in 2008, dedicated to intangible cultural heritage, Article 7-bis "Expressions of collective cultural identity" in which the legislator introduced only the commitments undertaken by Italy with the national laws that ratified the 2003 and the 2005 UNESCO Conventions, that are "subject to the provision of this Code if they are represented by material testimony and if the prerequisites and the conditions for the applicability of article 10 exist". Article 10 includes the list of cultural properties under the Code protection: according with this article, the intangible heritage is "protected" only in its tangible dimension.

6 Council of Europe Framework Convention on the Value of Cultural Heritage for Society (CETS No. 199), Faro, 27 October 2005. 
beliefs, knowledge and traditions. It includes all aspects of the environment resulting from the interaction between people and places through time;

b) a heritage community consists of people who value specific aspects of cultural heritage which they wish, within the framework of public action, to sustain and transmit to future generations.

According to the Faro Convention, "heritage community" means a human group that wants to support with public actions a cultural heritage considered worthy of being transmitted to future generations. The Faro Convention, unlike other international legal instruments, shifts the focus from the cultural heritage itself, to the relationship of communities "with the surrounding environment and their active participation in the process of recognition of cultural values, placing heritage as a resource at the centre of a vision of sustainable development and promotion of cultural diversity for the construction of a peaceful and democratic society" 7 .

Cultural heritage is recognized as part of the right to participate in cultural life, in the Universal Declaration of Human Rights of 1948, which in Article 27 proclaims: "1. Everyone has the right freely to participate in the cultural life of the community, to enjoy the arts and to share in scientific advancement and its benefits".

Even before the Faro Convention, UNESCO adopted the Convention for the Protection and Promotion of the Diversity of Cultural Expressions on 20 October 2005, ratified by Italy on 30 January 2007. The Convention "celebrating the importance of cultural diversity for the full realization of human rights and fundamental freedoms proclaimed in the Universal Declaration of Human Rights, and other universally recognized instruments", not only emphasizing the fundamental right of individuals and peoples to participate in culture (Article 2 and Article 5), but in particular recalling the theme of participation in a specific article:

Article 11 - Participation of civil society

Parties acknowledge the fundamental role of civil society in protecting and promoting the diversity of cultural expressions. Parties shall encourage the active participation of civil society in their efforts to achieve the objectives of this Convention.

In the international documents, the participatory approach prevails as part of the right of communities and individuals and as a possible tool for States to develop new strategies in the implementation of cultural policies. The theme is complex and highly contemporary, involving, in this global change of scenarios, the anthropological disciplines, international and cultural heritage laws.

In the 2003 Convention, participation is one of the key concepts of safeguarding, as recurrently stressed in various reports of the intergovernmental committee debates. Among the measures that can guarantee the viability of $\mathrm{ICH}$, the Convention calls for the implementation of inventories.

The analysis of the language Convention's text, which uses non-prescriptive language in most of its articles, makes it possible to understand the importance given to certain strategic points, in particular those concerning the way in which safeguarding measures are implemented, and the importance given to inventories in this direction. According to Article 11 of the Convention, each State Party, is required to take the necessary measures to ensure the safeguarding of $\mathrm{ICH}$ including communities, groups and relevant NGOs in the identification of elements.

7 Carmosino C. Il valore del patrimonio culturale fra Italia e Europa. La Convenzione quadro del Consiglio d'Europa sul valore del patrimonio culturale per la società // Aedon. 2013. No. 1. Available at: http:// www.aedon.mulino.it/archivio/2013/1/carmosino.htm (accessed: 14.03.2020). 
Article 11 - Role of States Parties

Each State Party shall:

a) take the necessary measures to ensure the safeguarding of the intangible cultural heritage present in its territory;

b) among the safeguarding measures referred to in Article 2, paragraph 3, identify and define the various elements of the intangible cultural heritage present in its territory, with the participation of communities, groups and relevant nongovernmental organizations.

Article 11 is more prescriptive than other ones ("take the necessary measures", "identify and define"). Each State, ratifying the Convention, is obliged to implement safeguarding plans to ensure that $\mathrm{ICH}$ can be transmitted from one generation to another. Transmission and participation processes are emphasized in the Convention: as indicated, only intangible elements that are recognized by communities as "theirs own ICH" are to be safeguarded.

Inventories are strictly connected to the safeguarding measures because they can raise awareness, can encourage creativity and "self-respect in the communities and individuals".

Article 12 - Inventories

1. To ensure identification with a view to safeguarding, each State Party shall draw up, in a manner geared to its own situation, one or more inventories of the intangible cultural heritage present in its territory. These inventories shall be regularly updated.

2. When each State Party periodically submits its report to the Committee, in accordance with Article 29, it shall provide relevant information on such inventories.

Indeed, the inventories process should not be static, the updating of them should ensure the recording of changes in identifying elements: communities are the bearers and the ones who create their $\mathrm{ICH}$ and keep it alive. Inventorying is an ongoing process and it cannot happen without the community involvement in identifying and safeguarding $\mathrm{ICH}$.

Article 15 - Participation of communities, groups and individuals

Within the framework of its safeguarding activities of the intangible cultural heritage, each State Party shall endeavour to ensure the widest possible participation of communities, groups and, where appropriate, individuals that create, maintain and transmit such heritage, and to involve them actively in its management.

From a democratic perspective and in participatory governance, a focus on civil society gives a voice to the communities, social groups, individuals who represent themselves through the diversity of their own $\mathrm{ICH}$. In accordance with this perspective, institutions do not have an autonomous and centralizing role, but instead become the subjects of a cultural mediation, facilitating cultural participation. Indeed, institutions continue to play an important role in the selection processes of the cultural heritage, but this function no longer falls exclusively on the shoulders of institutions. As a result of the new international regulatory context, there now exists a recognition of the need to understand the $\mathrm{ICH}$ elements through the transmission processes, in terms of viability and enhancement, and through the "living signs" that are constantly recreated, in an ever-new production of culture.

The new paradigms introduced by the Convention lead institutions to a new reflection on cultural heritage and force the scientific community, experts, ethnographic and anthropological disciplines to carefully analyse fieldwork research approaches and methodologies, bringing new principles into the process of identification and inventory of $\mathrm{ICH}$. Inventories are an integral part of safeguarding because they raise awareness about $\mathrm{ICH}$ and its importance for individual and collective identity. 
The new international regulatory context, involving the study, comparison, experimentation, and within the context of European Programmes ${ }^{8}$, has led the Lombardy Region Ethnography and Social History Archive to draw up an international inventory, shared on the inter-regional level of the European cross-border area. As such, to understand these developments and perspectives, we must first begin with an analysis of the activity of the Regional Archive operates.

\section{Regional policies on Intangible Cultural Heritage}

The Italian ratification of the 2003 UNESCO Convention was an opportunity to give continuity and consistency to a cultural action that the Lombardy Region Ethnography and Social History Archive has been operating since 1970s.

In the spirit of the 2003 Convention, the qualification of the intangible heritage as a "cultural asset" finds regulatory fulfilment in the Regional Law no. 27 of 23 October 2008, "Enhancement of the intangible cultural heritage", which recognizes this heritage and attests the willingness, at the institutional level, to enhance it in its various forms and expressions through the Regional Archive, following different lines of action, as reflected in Articles 1 and 2. The new Regional Law of Lombardy no. 25 of 7 October 2016 on "Regional policies on cultural matters - Regulatory reorganization" takes up the contents of former law no. 27, in particular in Articles 13 and 22:

Article 13 - Ethno-anthropological heritage and Intangible Cultural Heritage

1. The Region promotes and supports the knowledge, identification, safeguarding and enhancement of ethno-anthropological heritage and intangible cultural heritage in its territory or in communities of Lombard citizens residing abroad, in its various forms and expressions.

2. For the purposes of this law, intangible cultural heritage means, in accordance with the definition contained in the Convention for the Safeguarding of the Intangible Heritage, ratified by Italy with law no. 167, 2007, practices, representations, expressions, knowledge, as well as the tools, objects, artefacts and cultural spaces associated with them, which communities, groups and in some cases individuals recognize as part of their heritage, their history and their identity with particular regard to: a) traditions and oral expressions, including oral history, narrative and toponymy; b) music and traditional performing arts, represented in a stable or itinerant form, as well as street artistic expression; c) social customs, ritual and festive events, historical events; d) knowledge, practices, beliefs related to the cycle of the year and of life, to nature and to the universe; e) traditional knowledge and techniques related to productive, craft, commercial and artistic activities.

3. The Region promotes, furthermore, the creation of inventories of intangible cultural heritage and fosters its inclusion in the lists prepared by UNESCO, carrying out a consultancy and support function for the national and international institute in charge.

Article 22 - Ethnography and Social History Archive (AESS)

1. The Region, through the Ethnography and Social History Archive (AESS), promotes the knowledge, conservation, enhancement and public use of the audio-visual documentary heritage, as related to social life, popular traditions, socio-economic and landscape transformations, as well as to work, literature and oral history, singing and traditional music of the Lombardy region, with particular attention to ethno-anthropological assets, intangible cultural heritage, the Lombard language and its variants.

2. In particular, AESS:

a) guarantees the public use of funds, collections and collections owned by the region or by other affiliated subjects, consisting of texts, photographs, audio-visual media, sound documents also through the digitization and management of databases;

8 E. CH. I. - Italo-Swiss ethnographies for the enhancement of the intangible heritage project (Interreg Italy-Swiss Cooperation Programme 2007-2013) and AlpFoodway project (Interreg Alpine Space Programme 2014-2020). 
b) promotes knowledge of the ethno-anthropological heritage through the acquisition of historical and contemporary documentary funds, the study and research in the field with every available technical support and the creation of communication products;

c) promotes the safeguarding of the intangible cultural heritage also through the creation of regional inventories that favour the transmission between generations;

d) promotes knowledge of the Lombard language in its variants;

e) it also promotes knowledge of the documentary heritage relating to the First World War also through the general info-telematic archive of historical and documentary findings in conjunction with the territorial competent bodies, which provide for its constant updating.

In 2008, to promote the new Regional Law and spread the principles of the 2003 UNESCO Convention, was developed the travelling exhibition project "Culture in Movimento". The project has been carried out in cooperation with Local Authorities, Ethnographic and Local Museums, Ecomuseums, Mountain Communities, Provinces, Research Institutes, Foundations and Cultural Associations. The 2008 Regional Law "Enhancement of the intangible cultural heritage" introduced a new regional political strategy to identify, safeguard and enhance $\mathrm{ICH}$. And this was the first important instrument to start the process of implementing a Regional Register about Lombardy $\mathrm{ICH}$. The travelling exhibition was the first action to implement this idea, drawing the Inventory up with ICH communities and Local Associations, Cultural Operators, Local Authorities and spread the new cultural policies all around the regional territories.

In the context of the enhancement of intangible heritage, the recognition of the $\mathrm{ICH}$ in the regional legislative framework, sparked a new "season" in the two-year period 20102011, through the first call of the Lombardy Region, "Public call for the participating process for the implementation of the Lombardy Intangible Heritage Register (REIL)".

The REIL implementation, an identification and safeguarding tool introduces, in accordance with the 2003 Convention, a bottom-up procedure, directly involving heritage communities in the identification process of intangible assets. The model starts from the assumption that shared responsibility between institutions and civil society serves as an "aggregating force" in the application of participatory and shared enhancement models.

This new approach has allowed the Archive to experiment with models that involve diversified and heterogeneous professional skills (encouraging and facilitating dialogue between social actors), combining the knowledge of anthropologists as well as the knowledge of those who locally recognize intangible assets as part of their contemporary heritage. Through this first public call, the Archive included the Traditional Violin Craftsmanship in Cremona and the Lombardy Region Alpine Transhumance elements in its Register $(2011)^{9}$, which will be later included in the Representative List of Humanity.

We have to underline that not all the projects that had a financial support were included inside the Regional Register. We included elements, not submitting them for a Nomination process or filling Nominations for the Convention Lists: this is a National evaluation process. The Register is intended as a tool to map the regional ICH "with a view to safeguarding", involving communities in this complex process of identifying and inventorying, having them a privileged place in safeguarding it.

Since 2011, and up to 2019, the Regional Law has allowed for the publishing of Public Calls to support communities, Institutions, Associations and Local actors carrying out projects for the identification, fieldwork researches, and participatory safeguarding actions.

9 The forms are available with the video-documentation at the web address of the Intangible Search Inventory: www.intangiblesearch.eu (Lombardy Section). 
As a result of the listed assumptions and through mediating the needs of the "R. E. I. L. community", a first draft inventory was tested, directly involving the communities in its definition processes. This draft inventory form has developed, and has found fulfilment and wider sharing, in the context of European Programming, with the creation of an inventory that is open to the territory of the Alpine Macroregion Strategy ${ }^{10}$.

The inventory form was developed taking into account different documents including, the UNESCO layouts of the Application Dossiers, the UNESCO "Identifying and Inventorying Intangible Cultural Heritage Guidelines", ten cases of European and international inventories analysed by the Association for the Protection of Cultural Heritage Intangible (ASPACI), research carried out in 2010 for the Regional Archive ${ }^{11}$, and the Ministerial form BDI - Intangible Demo-ethnoanthropological Heritage, created by the Central Institute for Catalogue and Documentation and used at National level for the presentation of the proposals for the Nomination of the elements.

The UNESCO kit contains a proposal for a structure that identifies, through its six sections, the information considered essential by UNESCO for the element "storytelling" through an inventory form: the data for its identification, its characteristics, the persons and institutions associated with the element, the state of the practice, the conditions of its transmission and viability, the methodology of its identification and the documentation produced and/or available.

It is a model which introduces important innovations ${ }^{12}$. In particular, the model draws attention to the descriptive aspects that refer to the role of the communities, groups and organizations linked to the element, involved in the transmission and viability processes. Relevant to this process is the information relating to the transmission methodology and the safeguarding measures in place, as well as the possible threats to viability. In the development of the layout, the comparisons and analysis of inventories and forms developed by other institutions at the European and international level were also significant.

The Archive contains new information introduced by the Convention, which are relevant because in relation to the descriptive requests of the Application Dossier-ICH $02 \mathrm{a}$ number of key questions arise. Who are the bearers and practitioners of the element? What are the specific roles of communities and groups or other categories for the practice? What are their responsibilities? What are the ways in which communities participate? How are these elements transmitted? How is safeguarding applied?

These are some of the indispensable features of the Inventory that are defined as "narrative" and which explain, within the obvious limits of a cataloguing form, the cultural geog-

10 In the spirit of the Convention, and thanks to the work shared with partners from other Regions and international ones, the international inventory for the enhancement of the intangible cultural heritage of the Alpine cross-border regions between Italy and Switzerland has been published online (www.intangiblesearch.eu). This is one of the results of the project $\mathrm{E}$. $\mathrm{CH}$. I. - Italo-Swiss ethnographies for the enhancement of the intangible heritage (Interreg Italy-Swiss Cooperation Programme 2007-2013). Lombardy Region, project leader, collaborated for its development with Piedmont Region, Valle d'Aosta Autonomous Region, Bolzano Autonomous Province, Valais Canton, Ticino Canton and Grigioni Canton, different administrations territories, but linked by common cultures values. Through the AlpFoodway project (Interreg Alpine Space Programme 2014-2020) the Inventory, in its dynamic and participative approaches, has been open up to the communities of other Alpine Regions (Trentino Alto Adige, France, Slovenia, Austria and Germany).

11 In addition to the work by ASPACI, Participatory Identification of Intangible Cultural Heritage (Identificazione partecipativa del patrimonio culturale immaterial), in 2012 a new research was developed: ASPACI. Participation in Intangible Cultural Heritage Safeguarding: Ethnographic, Economic and Technological Aspects. Milan: Ethnography and Social History Archive, 2013.

12 Kit of the Convention for the Safeguarding of the Intangible Cultural Heritage. P. 15 // UNESCO. Available at: http://www.unesco.org/culture/ich/index.php?lg=en\&pg=00451 (accessed: 14.03.2020). See also the analysis edited by ASPACI. Identificazione partecipativa del patrimonio culturale immateriale. 2011. P. 6-37 (Ibid.). 
raphy of a territory, through constantly evolving living practices, which, as demonstrated, continue to be the centre of the communities and establish links between tradition and contemporary values. This is a rather complex process and, in fact, the new role of communities and the concept of participation triggered significant changes in the fieldwork approaches, identification and inventorying, enhancement and restitution methods, and forced institutions to deeply reflect on and rethink governance strategies with a renewed attention. The work is complex and continues to progress and, in light of ongoing and foreseeable future developments, requires continuous collaboration with institutions and civil society.

\section{Examples and best practices}

Starting from the Lombardy Register the Intangible Search inventorying process has been extended to the Alpine Regions through different European programme and projects.

The Rye Bread Festival is a good example of a safeguarding participatory measure. Started at regional level in the Aosta Region, in Lombardy Region and in Canton Grigioni (Switzerland), the Festival has grown into a transnational one joining communities from eight Alpine regions in six countries (Aosta, Lombardy and Piemonte Regions in Italy, Upper Gorenjska Region in Slovenia, Parc de Bauges in France, Upper Bavaria in Germany, Canton Grigioni and Canton Valais in Switzerland).

Every year, at the same day of October, all the Regions open their community's ovens to make rye bread. Started in the Aosta Valley, at regional level, the Rye Bread Festival is an example that has become a transnational one, joining Alpine communities inside a ritual, make traditional rye-bread, in which the communities' know-how is still alive, and raise awareness of the common $\mathrm{ICH}$ across regions and countries. For the fifth-year edition, in this time of Covid emergency, we developed a new format to go inside community's homes and connect them (all over the countries) through digital instruments and streaming devices. We developed with local communities this approach, to maintain the spirit of the event, to create a new common shared experience in making bread, and for the first time, at the same time, to put in contact communities of different Regions through digital devices.

Thinking about Educational programme on $\mathrm{ICH}$ the Politecnico University of Milan School of Design launched a course in Exhibition Design Studio in 2017. The course is based on the Intangible Search Inventory (www.intangiblesearch.eu) to select five collections, to share information with the students and to understand the importance of $\mathrm{ICH}$. The course aims at enhancing the cultural heritage of the Alpine Mountain's identity, focusing on design solutions that relate to exhibit design in terms of widespread museums and temporary exhibitions. This is only an example for integrating intangible cultural heritage in University Programmes. Similar methods could be used to raise awareness with the public schools, in different context of learning to learn more about $\mathrm{ICH}$ : awareness raising is a key to safeguarding $\mathrm{ICH}$.

Fifty students from various countries designed two different typologies of projects to valorise some Alpine ICH practices and rituals. The first project lays itself within the regional landscape, the second one in the urban context of the square Città di Lombardia in the city centre of Milan (the Lombardy Region Institutional District). The projects presented how the cultural heritage of the Alpine mountain regions can be shared to urbans thanks to design new models of cultural experience and, hence, demonstrate the relationship between rural and urban areas.

The collections were inspired by the Lombardy Register elements:

- traditional carpet pezzotti: it's a rustic and coloured traditional carpet, made of waste textile from Valtellina; 
- handmade footwear pedù: Lanzada town's (Valmalenco) footwear made of a thick fabric sole with velvet ribbed and laced upper sewn onto it;

- rye bread pan de séghel: it's a particular type of bread made of rye wheat which still today is consumed throughout "Valtellina" mountain area;

- carnival and wooden mask sculptors: Schignano's Carnival is part of the Alpine ones;

- bells and bell-ringers: since the middle ages the sound of bells has played a major role in the Bergamo's area celebration of religious events and in calling public gatherings.

At the end, talking about ICH Convention methodology, the AlpFoodway Alpine Space Project in which all partners started a bottom-up process involving local communities to identify and inventorying Intangible Alpine Food Heritage and including more than 150 elements about food production, agricultural knowledge, rituals, traditions in a spirit of recognition of a common cultural heritage. Alpine Food Heritage is the set of sustainable production and consumption practices, knowledge and skills, productive landscapes and locally produced traditional food in the Alpine regions. It depends on commons, shared goods and services, and on mutual assistance.

With the support of the Macroregional Strategy EUSALP ${ }^{13}$ Lombardy Region has been developing an Inter Directorates Task Force that link Culture, Agriculture, Environment, Local Mountains to support the dissemination of the AlpFoodway Methodology results also in the context of the UNESCO 2003 Convention ${ }^{14}$.

\section{Conclusions}

One of the tools used to develop new strategic regional policy is the Lombardy Register of the Intangible Heritage (REIL). According to the Guidelines and 2003 UNESCO Convention for the Safeguarding of Intangible Cultural Heritage (2003 Convention), REIL was implemented in accordance with communities participatory processes: www.intangiblesearch.eu (Lombardy Section).

The Lombardy Region Register, in the context of European and International projects, was opened up to international heritage communities, Institutions, Cultural Organisations and Regions of the Alpine Macroregional Strategy EUSALP ${ }^{15}$.

As a result of this new regional cultural policy, the Intangible Search Inventory was established, overseen by the Archive which coordinates safeguarding measures, actions and projects. The Intangible Search Inventory is a community based inventory that adopts the 2003 Convention principles for the safeguarding of $\mathrm{ICH}$, and works to apply the key ideas of the Convention itself, including participation and communities, in the identification and description of the ICH elements.

The Archive is also in charge of the production, collection and enhancement of multimedia documentation on $\mathrm{ICH}$. This extends to multimedia collections regarding rituals,

13 "The Alpine macro-regional strategy would provide an opportunity to improve cooperation in the Alpine States as well as identifying common goals and implementing them more effectively through transnational collaboration. EUSALP constitutes a strategic agenda that should guide relevant policy instruments at EU, national and regional level, by closely aligning and mutually reinforcing them". Available at: http://alpine-region.eu (accessed: 14.03.2020).

14 All the studies and results are available the Alpine Space project website: https://www.alpinespace.eu/projects/alpfoodway/en/home (accessed: 14.03.2020). Elements from the Alpine Regions: www.intangiblesearch.eu (accessed: 14.03.2020).

15 AlpFoodway Project - Alpine Space Programme 2014-2020. Available at: https://www.alpinespace.eu/projects/alpfoodway (accessed: 14.03.2020). 
social habits, traditional technical knowledge, oral expressions and traditional music. Some of this thematic fieldwork researches and multimedia materials can be further explored on www.intangiblesearch.eu.

The main objectives of Intangible Search are:

- identifying and inventorying the living $\mathrm{ICH}$ taking into account various domains of $\mathrm{ICH}$ which, according to the Unesco Convention, include e. g. oral tradition, performing arts, social practices, rituals and festive events, knowledge and practices concerning nature and the universe, traditional craftsmanship;

- spreading and increasing awareness about $\mathrm{ICH}$ in a very widespread manner, also holding discussions and seminars for the purpose of providing a large number of parties operating in the field of $\mathrm{ICH}$.

The challenge is to implement new strategies and support communities and Local Authorities with a view to the future, allowing participation and civil society involvement to contribute spreading $\mathrm{ICH}$ values and benefit, enlarging the actors and the education about $\mathrm{ICH}$.

\title{
References
}

Carmosino, Cinzia. 2013. II valore del patrimonio culturale fra Italia e Europa. La Convenzione quadro del Consiglio d'Europa sul valore del patrimonio culturale per la società. Aedon 1. Available at: http://www.aedon.mulino.it/archivio/2013/1/carmosino.htm (accessed: 14.03.2020).

Leydi, Roberto. 1972. Le trasformazioni socio-economiche e la cultura tradizionale in Lombardia. Cultura tradizionale in Lombardia, ed. by Roberto Leydi: 7-11. Milan, Department of Culture.

\section{Нематериальное культурное наследие и процесс инвентаризации в регионе Ломбардия}

\author{
М. А. Лаваньино
}

Для цитирования: Lavagnino, Maria A. Intangible Cultural Heritage and inventory process of the Lombardy region // Правоведение. 2020. T.64, № 1. С. 68-79.

https://doi.org/10.21638/spbu25.2020.106

В статье описывается опыт регионального государственного учреждения, участвующего в процессе составления Регионального регистра Нематериального культурного наследия (Intangible Cultural Heritage, ICH) в духе Конвенции 2003 г. Архив этнографии и социальной истории региона Ломбардия (Archivio di Etnografia e Storia Sociale, AESS) работает с 1970-х годов в рамках регионального учреждения по приумножению традиционного наследия региона Ломбардия. С того времени Архив использовался для осуществления полевых работ и этнографических исследовательских проектов и пополнялся документами, фотографиями и аудиовизуальной документацией. Ратификация Италией Конвенции ЮНЕСКО 2003 г. дала возможность сохранить преемственность культурной деятельности, осуществляемой AESS с 1970-х годов. Региональный закон от 23.10.2008 № 27 «Об укреплении нематериального культурного наследия» и новый Региональный закон Ломбардии от 07.10.2016 № 25 «Региональная политика в области культуры - регулятивная реорганизация» позволили провести инвентаризацию с участием всех заинтересованных сторон и принять в Италии новаторское законодательство. В результате осуществления новой региональной культурной политики была создана опись выявленного нематериального наследия, курируемая AESS, который координирует охранные меры, действия и проекты. Опись выявленного нематериального наследия - это сформиро- 
ванный благодаря деятельности местных сообществ реестр, основанный на принципах Конвенции 2003 г. об охране ICH и применении ключевых идей самой Конвенции, включая участие местных сообществ в идентификации и описании элементов ICH. Архив также отвечает за производство, сбор и расширение мультимедийной документации по ICH, в том числе мультимедийных коллекций, касающихся ритуалов, социальных привычек, традиционных технических знаний, устного творчества и традиционной музыки. Некоторые из тематических полевых исследований и мультимедийных материалов доступны на сайте www.intangiblesearch.eu.

Ключевые слова: региональное право, живое наследие, идентификация, инвентаризация, сообщества, охрана, процессы участия.

Статья поступила в редакцию: 28 сентября 2020 г. Рекомендована в печать: 23 декабря 2020 г.

Лаваньино Мария Агостина - Архив этнографии и социальной истории региона Ломбардия, Италия, 20124, Милан, пл. Читта ди Ломбардия, 1; maria_agostina_lavagnino@regione.it 